\title{
Jugoslavenska narodna armija u Socijalističkoj Republici Hrvatskoj 1959. - 1969. godine
}

\author{
BOJAN DIMITRIJEVIĆ \\ Institut za savremenu istoriju \\ Beograd, Srbija \\ bojands1@gmail.com
}

\begin{abstract}
U tekstu koji slijedi dat ćemo pregled organizacijskoga razvoja Jugoslavenske narodne armije u Narodnoj/Socijalističkoj Republici Hrvatskoj tijekom 60-ih godina. U tom periodu provedeno je nekoliko reorganizacija Armije. Cijelo desetljeće počinje reorganizacijom „Drvar” u drugoj polovini 1959., na bazi uvođenja koncepcije takozvane općenarodne obrane i očekivanoga nuklearnog rata, preko nekoliko reorganizacija između 1964. i 1968., pa do vremena nakon agresije snaga Varšavskoga pakta na Čehoslovačku. Članak je nastao na bazi arhivske građe koja se čuva u Upravi za organizaciju, Vojnom arhivu i Muzeju Jugoslovenskoga ratnog vazduhoplovstva, sve u sastavu Ministarstva odbrane Republike Srbije u Beogradu, te dvaju prethodno objavljenih autorovih radova koji se bave istom tematikom, ali u širem vremenskom kontekstu.

Ključne riječi: Jugoslavenska narodna armija; Socijalistička Republika Hrvatska; Jugoslavija; organizacija; jedinice; kopnena vojska; ratno zrakoplovstvo; mornarica
\end{abstract}

Poslije otkazivanja programa američke vojne pomoći, postupnog, ali sveobuhvatnog izmirenja sa Sovjetskim Savezom i diplomatskoga okretanja Africi i Aziji došlo je do zaokreta u promišljanju o obrambenoj politici Jugoslavije oko 1958. godine. U to vrijeme počelo se smatrati da je nevezanost za bilo koji od dva europska vojna bloka pozitivan ishod političke i diplomatske borbe Jugoslavije nakon 1945., ali i dobar model ponašanja na međunarodnoj sceni. Na valu takva razmišljanja počelo je i okretanje onome što se smatralo pozitivnim iskustvom - partizanskoj borbi u Drugom svjetskom ratu. U skladu s tim razmišljanjima vojnoga vrha, a radi daljnjega usavršavanja obrane Jugoslavije, 1958. izrađena je nova koncepcija obrane, poznatija pod nazivom Strategija općenarodnog rata. ${ }^{2}$

1 DIMITRIJEVIĆ, „Organizacija Jugoslovenske narodne armije u Hrvatskoj 1945-1965. godine”, 301-320; DIMITRIJEVIĆ, „Organizacija Jugoslovenske narodne armije u Hrvatskoj 1966-1991. godine", 119-138; DIMITRIJEVIĆ, Jugoslavenska narodna armija u Hrvatskoj $i$ Sloveniji 1945. - 1968. Autor upućuje i na fond 1211 (5. vojna oblast) u Hrvatskom državnom arhivu, koji vremenski pokriva ovo razdoblje sačuvanim fotografijama.

2 SR-VA-JNA, kut. 24, fasc. 3, 3/2. 
Reorganizacija Jugoslavenske narodne armije u okviru plana „Drvar” 1959. - 1961.

Tijekom 1959. na osnovi te koncepcije započela je velika reorganizacija Jugoslavenske narodne armije (JNA), poznatija pod nazivom „Drvar”. U skladu s planom „Drvar” napravljene su brojne formacijske promjene u jedinicama. ${ }^{3}$

$\mathrm{Za}$ najviše strategijske vojne komande umjesto armijske oblasti (naziv iz 1956.) sada se upotrebljavao termin armija. Proširen je broj postojećih vojnih područja u okviru armija stvaranjem nekoliko novih vojnih područja. Svaka armija kopnene vojske imala je po četiri vojna područja. Bila su sastavljena od pješadijskih i oklopnih divizija kopnene vojske, samostalnih brigada i pukova i odgovarajućih rodovskih, teritorijalnih i partizanskih jedinica. Najveći broj vojnih područja u ratu bi od operativnih sastava formirao korpuse i vojna područja teritorijalno-partizanske namjene. Neka manja vojna područja obično su bila sastavljena od brigada i pukova, a planom je bilo predviđeno da u ratu razvijaju i divizije. Veličina vojnih područja ovisila je o sastavu, teritoriju - zoni odgovornosti, broju jedinica, odnosno mjestu, ulozi i namjeni prema predviđanjima i planu upotrebe, i dijelila su se na tri varijante (I., II. i III. varijanta). ${ }^{4}$

Planom „Drvar” formirano je 11 divizija (pješadijskih i oklopnih) tipa A i 25 divizija tipa B, ili ukupno 36 divizija, u miru i u ratu. Najbitnija razlika između tih tipova divizija bila je u opremljenosti i brojnom stanju u miru. Divizija tipa A imala je najbolje naoružanje i opremu, a divizija klasifikacije $\mathrm{B}$ u miru je imala samo mobilizacijsku jezgru (odnosno pet pješadijskih četa umjesto pet pukova). Divizije tipa A bile su popunjene vojnicima i starješinama $80-90 \%$, neke i $100 \%$ od ratne formacije, i dovoljno ojačane jedinicama rodova, a divizije klasifikacije B imale su samo minijaturne komande i jedinice za razvoj prema ratnoj formaciji, sa samo oko 700 ljudi. Pored pješadijskih, postojale su i dvije oklopne divizije. ${ }^{5}$

Međutim, planom „Drvar” unutar kopnene vojske JNA prešlo se na takozvanu petornu formaciju pod utjecajem američke formacije Pentomic. Tako su divizije kategorije $A$ trebale imati po pet pješadijskih pukova, a divizije kategorije $B$ pet pješadijskih četa, koje bi razvijale pukove u ratu. Tom je promjenom bataljon kao organizacijska forma, osim ako nije bio samostalan, bio ukinut. Divizijama su sada vraćeni partizanski nazivi koji su korišteni tijekom Drugoga svjetskog rata sve do 1948. godine.

U samoj 5. armiji na teritoriju Narodne Republike (NR) Hrvatske bile su dvije divizije tipa A: 6. lička proleterska pješadijska u Karlovcu i 14. proleterska pješadijska (bivša 56.) u Varaždinu. Iz sastava sarajevske 7. armije u Kninu

3 SR-MO-SLJR-UO, Nar. VKOS, str. pov. 9, 27. 7. 1959. i Nar. III uprava GŠ JNA, str. pov. 293, 5. 8. 1959.

${ }^{4}$ Razvoj oružanih snaga SFRJ 1945-1985 (dalje: Razvoj OS SFRJ), knj. 3: Kopnena vojska JNA, tom I, 99-101.

5 Isto, 101. 
je bila 19. dalmatinska (bivša 25.), a u Osijeku 12. slavonska (bivša 58.). Obje divizije tipa A iz 7. armije bile su ustvari u Hrvatskoj.

I nove divizije tipa $\mathrm{B}$ dobile su nazive prema partizanskim divizijama iz Drugoga svjetskog rata: 13. primorsko-goranska (Delnice), 32. hrvatska (Zagreb) i 35. lička (Gospić). Iz 7. armije od devet divizija tipa B samo je jedna (9. dalmatinska) bila u Hrvatskoj - u Kninu, ali samo tijekom 1959. godine.

Tako su u sastavu 5. armije s komandom u Zagrebu (komandant general-pukovnik Rade Hamović) bili:

- 20. oklopna divizija u Sisku (s tri oklopna puka: 2. u Jastrebarskom, 31. u Dugom Selu i 282. u Petrinji)

- Vojno područje Zagreb (komandant general-major Josip Antolović) sa sljedećim jedinicama:

- 6. lička pješadijska divizija A u Karlovcu (pukovi: 8. proleterski u Karlovcu, 9. proleterski u Novome Mestu, 10. proleterski u Zagrebu, 106. u Novome Mestu i 588. u Zagrebu) ${ }^{6}$

- 14. proleterska pješadijska divizija A „Boris Kidrič” u Varaždinu (pukovi: 11. proleterski u Ptuju, 14. proleterski u Varaždinu, 16. proleterski u Čakovcu, 73. u Koprivnici i 140. u Bjelovaru)

- 32. hrvatska pješadijska divizija B u Zagrebu (74., 178., 257., 291. i 622. pješadijska četa)

- Vojno područje Rijeka (komandant general-potpukovnik Srećko Manola, potom general-major Tomica Popović), u čijem u sastavu bile:

- 13. primorsko-goranska pješadijska divizija B u Delnicama (79., 157., 228., 245. i 253. pješadijska četa)

- 35. lička pješadijska divizija B u Gospiću (38., 142., 187., 546. i 580. pješadijska četa). ${ }^{7}$

$\mathrm{U}$ ovom kratkom popisu nisu navedene ostale samostalne - rodovske jedinice koje su ulazile u sastav vojnih područja (artiljerijske, inženjerijske, jedinice veze ili ABKO). I u okviru njih napravljen je niz promjena. ${ }^{8}$ Kao udar-

6 U dokumentu je rukom dopisano „kad se stvore uslovi”, što znači da su u realnosti postojala samo prva tri spomenuta puka, a druga dva trebalo je kasnije formirati. SR-MO-SLJRUO, Nar. III uprava GŠ JNA, str. pov. 293, 5. 8. 1959.

7 SR-MO-SLJR-UO, Nar. III uprava GŠ JNA, str. pov. 293, 5. 8. 1959.; Razvoj OS SFRJ, knj. 3: Kopnena vojska JNA, tom I, 100-101.

8 U artiljeriji su pojedini pukovi reorganizirani i smanjeni na veličinu diviziona. Rasformirana su dva artiljerijsko-izviđačka diviziona (Otočac, Zagreb) i 966. artiljerijski nastavni centar u Varaždinu. Radi pojačanja protuoklopne obrane protutenkovski artiljerijski puk u Križevcima preformiran je u brigadu. Na tom pravcu formirane su samostalne posadne baterije u Varaždinu i Križevcima. U rodu inženjerije došlo je do veće promjene, formiranja i reorganiziranja, pa je tako 5. armija imala inženjerijske pukove u Zagrebu (213.), Karlovcu (333.), odnosno bataljone u Petrinji, Bjelovaru i Pazinu, i nekoliko specijaliziranih samostalnih četa. U rodu veze na razini armije bio je puk veze u Samoboru (367.), za tri vojna područja po jedan bataljon. $U$ jedinicama $A B K O$ svako je vojno područje imalo svoju četu $\mathrm{ABKO}$, a armija bataljon ABKO. SR-MO-SLJR-UO, Nar. III uprava GŠ JNA, str. pov. 293, 5. 8. 1959. 
ne, ističemo oklopne jedinice: 5. armija imala je pored 20. oklopne divizije kao samostalnu 265. oklopnu brigadu u Bjelovaru, koja je stigla iz Ilirske Bistrice. Oklopne bataljone jačine dviju četa (27 tenkova) imale su 6. i 14. proleterska divizija. ${ }^{9}$

Od ostalih važnijih promjena na području 5. armije ističemo da je rasformirana 33. pješadijska divizija u Rijeci, na čijem je mjestu formirana 25. pješadijska brigada, a u Puli je formiran 36. pješadijski puk umjesto prijašnjega 965. nastavnog centra. Radi grupiranja gardijskih jedinica oko Beograda premješten je 181. gardijski puk iz Zagreba u Valjevo. Napravljen je niz manjih promjena u jedinicama rodova i službi kopnene vojske, poput formiranja sedam skladišnih grupa u skladu s novom organizacijom. ${ }^{10}$

Na dan 1. travnja 1960. 5. armija imala je po ratnoj formaciji 218943 ljudi, a bila je popunjena čak 108\% (dakle, bilo je i viška ljudstva koje se moglo uključiti u jedinice), što je značilo da je u popuni jedinica bilo 236383 ljudi. Ta brojka bila je negdje ispod četvrtine ukupne ratne armije JNA u tom trenutku, koja je iznosila 1017451 ljudi po formaciji ili 1060114 popune „na licu”.11

U sastavu sarajevske 7. armije bilo je novoformirano Vojno područje Slavonska Požega (komandant general-major Đuro Dulić), koje je u svojem sastavu imalo sljedeće jedinice na području NR Hrvatske:

- 12. slavonska pješadijska divizija A s komandom u Osijeku (sastava pet pukova: 49. u Vinkovcima, 446. u Osijeku i tri puka na teritoriju NR Bosne i Hercegovine, u Tuzli, Brčkom i Doboju)

- samostalne jedinice ovoga vojnog područja: 7. proleterski pješadijski puk u Virovitici, 264. pješadijska brigada (prijašnja 22.) u Slavonskoj Požegi i 247. oklopna brigada u Osijeku.

Sedma armija imala je u Slavoniji nešto jače protuoklopne snage: 158. protuoklopnu brigadu (dotad puk) u Đakovu, 288. protuoklopni divizion u Novoj Gradiški, koji je u ratu razvijao puk, i posadnu bateriju u Đakovu, koja bi u ratu razvijala baterije u Daruvaru, Našicama, Osijeku i Đakovu. Te snage nadovezivale su se na protuoklopne snage 5. armije dalje na istom pravcu. Dio rodovskih snaga 7. armije bio je u NR Hrvatskoj: 497. inženjerijski puk u Slavonskom Brodu i manje jedinice u garnizonima Vukovar, Vinkovci, Slavonski Brod i Slavonska Požega. ${ }^{12}$

Pored podjele aktivnih jedinica na one tipa A ili B, shodno njihovoj mirnodopskoj popuni, u tom periodu uvodi se veliki broj „ratnih” - teritorijalnih jedinica. One bi se formirale u ratu i bile bi popunjene iz rezervnoga sastava.

9 SR-VA-JNA, kut. 437, fasc. 2, 9/1-42.

10 SR-MO-SLJR-UO, Nar. III uprava GŠ JNA, str. pov. 293, 5. 8. 1959.

11 SR-VA-JNA, kut. 26, fasc. 3, 7/20. Popuna je bila zadovoljavajuća i u četiri armije u ratnoj formaciji iznosila je 103-108\%, a nešto manja (93\%) bila je u Jugoslavenskoj ratnoj mornarici, koja se popunjavala samo sa svojega teritorija i gdje nije bilo moguće osigurati popunu svih specijalnosti.

12 SR-MO-SLJR-UO, Nar. III uprava GŠ JNA, str. pov. 293, 5. 8. 1959. 
To je bilo u duhu strategija takozvanoga općenarodnoga obrambenog rata (ONOR-a), ali su se rješenja i njihova forma mijenjali u svakoj od reorganizacija tijekom 60 -ih godina. Od prijašnjih posadnih i stražarskih ili jedinica narodne vojske od kraja 40-ih sada se prešlo na partizanske jedinice, potom na teritorijalne pješadijske pukove. One su bile organizirane na jedan način u okviru plana „Drvar”, na drugi u okviru plana „Drvar 2" i na treći način u okviru plana „Snaga”. To pokazuje da je postojalo očigledno lutanje u vojnom vrhu u pitanju promišljanja o popuni ratne vojske i provođenju mobilizacije.

Prema planu „Drvar”, u ratnoj vojsci najprije je „formirano” 25 samostalnih pješadijskih pukova tipa $B$ na teritoriju Hrvatske, a potom je njihov broj smanjen na tri, u Umagu i Bjelovaru te jedan takav u Đakovu, koji je bio pod komandom 7. armije. ${ }^{13}$

U sastavu Komande graničnih jedinica s komandom u Beogradu bile su jedinice koje su osiguravale granični pojas Federativne Narodne Republike Jugoslavije, pa tako i NR Hrvatske. To je bila 199. granična brigada u Podravskoj Slatini. Pomorska 31. granična brigada u Splitu bila je u sastavu Ratne mornarice i bila je mješovitoga sastava, sastavljena od pomorskih i jedinica kopnene vojske.

U skladu s planom „Drvar” pristupilo se detaljnoj reorganizaciji i Jugoslavenskoga ratnog zrakoplovstva. Ključna izmjena bila je ta da je zrakoplovstvu dodana i protuzračna obrana, pa se taj vid Armije otad zove Ratno vazduhoplovstvo i protiv vazdušna odbrana (RV i PVO). Dva zrakoplovna korpusa (Beograd, Zagreb) ukinuta su, a njihove zrakoplovne divizije bile su preformirane u vazduhoplovne komande (vak): zagrebačka 32. u 5. vak-u (komandant general-major Radoslav Jović), a zadarska 21. u 9. vak-u (komandant general-major Radoje Ljubičić). Njezina komanda prebazirana je s aerodroma Zemunik na aerodrom Mostar 1960. godine. Deveta zrakoplovna komanda obuhvaćala je jedinice na aerodromima Mostar i Zemunik, kao i u hidrobazi Divulje, i određena je za suradnju s Jugoslavenskom ratnom mornaricom (JRM). ${ }^{14}$

Prebazirane su i neke zrakoplovne jedinice radi kompletiranja svake od zrakoplovnih komandi. Tako je početkom 1960. godine 117. lovački puk prebaziran iz Batajnice na Pleso, a 88. lovačko-bombarderski puk iz Cerklja u Batajnicu. ${ }^{15}$ Potom, 109. puk prešao je s aerodroma Pleso u Cerklje, a 97. protupodmornički puk u svibnju 1960. u Mostar ${ }^{16}$ Prebaziranje borbenih jedinica u Mostar bilo je uvod u predislokaciju školskih jedinica u Zadar.

U trenutku reorganizacije „Drvar” RV i PVO imao je na raspolaganju 14 aerodroma kategorije A, od kojih su na prostoru Hrvatske bili Pula, Zemunik-Zadar i Pleso-Zagreb. Planeri RV i PVO računali su i na dvije proširene

13 SR-MO-SLJR-UO, Nar. III uprava GŠ JNA, str. pov. 393, 30. 9. 1959.; SR-VA-JNA, kut. 26, fasc. 3, 7/14-15.

14 SR-MJRV-RVPVO, Istorijat Komande JRV 1955-1961, „Podaci iz izveštaja koji je dostavljen VKOS FNRJ i DSPNO o borbenoj gotovosti RV za 1959. godinu”.

15 SR-MJRV-RVPVO, kut. 31, „Istorijat 117. lovačkog puka za 1960. godinu”.

${ }_{16}$ Druga eskadrila Narodnooslobodilačke vojske Jugoslavije 1944-1984. 
dionice na autocesti Beograd - Zagreb, koje su se uz izvjesne dopunske radove mogle koristiti za prihvat manjih jedinica mlazne avijacije. ${ }^{17}$

Prema planu „Drvar”, sada dolazi do formiranja „objekata PVO” - objedinjenih jedinica protuzračne obrane od dotadašnjih protuavionskih jedinica $u$ Zagrebu, Puli, Rijeci, Karlovcu i Sisku, prije svega s idejom jedinstvene obrane jednoga „objekta” - grada, kao važnoga vojnog ili pomorskog cilja. Dio samostalnih baterija trebao je u ratnoj formaciji razvijati objekte PVO-a, a dio snaga i dalje je imao namjenu protuavionske zaštite trupnih jedinica. ${ }^{18}$

U skladu s planom „Drvar” napravljene su brojne formacijske promjene i u jedinicama mornarice, ali tek 1960. jer je naredba za reorganizaciju JRM-a sastavljena 28. prosinca 1959. godine. Tim planom preformirana je Komanda JRM-a, postajući združena komanda koja je pored flote s plovnim jedinicama u svoj sastav dobila tri vojna područja s kopnenim i plovnim snagama. ${ }^{19} \mathrm{Ta}$ su područja bila s komandama u Titogradu, Mostaru i Šibeniku. Jedino isključivo pomorsko područje bilo je sa sjedištem u Puli (komandant kapetan bojnoga broda Benko Matulić). Vojno područje Šibenik (komandant general-potpukovnik Gligorije Mandić) bilo je u početku reorganizacije 1959. formirano pri 7. armiji, pa je tek kasnijom naredbom prešlo u sastav mornarice. U njegovu sastavu bila je 19. dalmatinska pješadijska divizija A i 9. dalmatinska pješadijska divizija $\mathrm{B}$, obje s komandama u Kninu.

Od plovnih jedinica, Komanda JRM-a imala je 4. divizion razarača, 6. divizion eskortnih razarača, 11. divizion torpednih čamaca, 16. divizion minolovaca i novoformiranu Podmorničku komandu. U tom periodu u sastav mornarice ulaze i dvije podmornice domaće izrade, "Sutjeska” i "Neretva”. ${ }^{20}$ Vojnopomorska područja imala su u svojem sastavu odrede torpednih čamaca, patrolnih brodova, minolovaca, minopolagača, „raspremljenih” i pomoćnih brodova, koji su se svrstavali u flotile ratnih brodova. ${ }^{21}$

17 SR-MJRV-RVPVO, Istorijat Komande JRV 1955-1961, „Podaci iz izveštaja koji je dostavljen VKOS FNRJ i DSPNO o borbenoj gotovosti RV za 1959. godinu: stanje aerodroma i njihovo uređenje".

18 SR-VA-JNA, kut. 26, fasc. 3, 7/18; SR-VA-JNA, kut. 168, fasc. 1, 26/1 (nova formacija jedinica PVO-a).

19 SR-MO-SLJR-UO, III uprava, str. pov. 531, 28. 12.1959.

20 SR-MO-SLJR-UO, III uprava, str. pov. 531, 28. 12. 1959.; KOMAR, Podmorničarstvo Jugoslavije, 91-97.

21 Početak 60-ih godina obilježio je i velik problem nepopunjenosti brodova prvoga ešalona Jugoslavenske ratne mornarice. Naime, oko trećine brodova nalazilo se u remontu, pa se na njih nije moglo računati u trenutku eventualnoga početka borbenih djelovanja. Bio je ispravan jedan od tri razarača, dva od tri eskortna razarača, 16 od 21 patrolnog broda, 27 od 44 torpedna čamca, 20 od 37 minopolagača i 16 od 36 minolovaca. Upozoravalo se i na slabiju realizaciju flotnoga programa i izgradnje novih brodova i veću prosječnu starost flote. Tako su na dan 1. ožujka 1960. od 607 brodova (uključujući i riječnu flotilu) 172 bila neispravna. Više od trećine neispravnih brodova bilo je ratnih. Osobito je bila alarmantna činjenica da su u tom periodu do 1962. posebno iz stroja izostajali eskortni razarači i podmornice. Razvoj OS SFRJ, knj. 5: Ratna mornarica, 84-87. 
Vjerojatno je uočeno da je za Komandu JRM-a opterećenje da izravno zapovijeda i vodi brigu o plovnim sastavima pored rukovođenja vojnim područjima, divizijama i drugim većim sastavima. Tako je prema naredbi od 29. lipnja 1961. formirana 1. flotila ratnih brodova, u koju su ušle plovne jedinice, odnosno divizioni: 4. razarača, 6. eskortnih razarača, 11 . torpednih čamaca i 12. desantnih brodova. U mornarici je provođenjem plana „Drvar” učinjen niz organizacijsko-formacijskih promjena. Ali obim je bio toliko velik da je posao s preformacijama trajao sve do 1962. godine! $!^{22}$

Te 1962. otišlo se korak dalje: Komanda Ratne mornarice preformirana je u 4. armiju, obuhvaćajući tako ne samo mornaričke jedinice nego i sve kopnene snage u zahvatu obale i zaleđa. Smatralo se da je to pomak u integraciji svih snaga na jadranskom vojištu. ${ }^{23}$ Sad je jedna vidovska komanda (komanda mornarice) transformirana u komandu armije (4.) intervidovskoga karaktera. Ona je objedinjavala i izvršavala zadatke mornarice i kopnene vojske ne samo na obali i otocima nego i u zaleđu jadranske obale. Zbog toga je u komandi te armije uvedena funkcija pomoćnika komandanta armije za kopnenu vojsku, visokoga čina i položaja i s ovlaštenjima da rješava mnoga pitanja kao što su koordinacija, obuka, sve vrste vježbi, razmještaj i vođenje kadrova i drugo. Kao i za kopnenu vojsku, u 4. armiji komandant je imao i pomoćnika za mornaricu, koji je u stručnom smislu bio odgovoran za mornaričke ili mornaričko-tehničke poslove. ${ }^{24}$

Konačno, izvan trupnih snaga promjene izvedene prema planu „Drvar” odnosile su se i na strukturu pripadnika Službe sigurnosti JNA, poznate pod skraćenicom KOS (Kontraobavještajna služba). Prema naredbama od 10. ožujka / 26. svibnja 1960., pri operativno strategijskim grupacijama: armijama, odnosno komandama JRM-a i RV i PVO-a formiraju se kontraobavještajni detašmani kao organizacijske jedinice Službe sigurnosti. Njihov zadatak bio je praćenje rada zagraničnih centara stranih obavještajnih službi usmjerenih prema JNA, kao i stvaranje agenture u zagraničnom prostoru koji je gravitirao prema jugoslavenskom teritoriju. Detašman u Zagrebu obavljao je zadatke prema Mađarskoj, a detašman u Rijeci prema Italiji. ${ }^{25}$

22 SR-MO-SLJR-UO, DSNO, str. pov. 284, 29. 6. 1961.

23 SR-MO-SLJR-UO, DSNO, str. pov. 188, 2. 6. 1962. Ta promjena nije bila predviđena prvobitnim planom „Drvar” iz 1959. godine.

24 Razvoj OS SFRJ, knj. 5: Ratna mornarica, 101.

25 SR-MO-SLJR-UO, Nar. VKOS FNRJ, pov. br. 33, 10. 3. 1960. i Nar. III uprava GŠ JNA, str. pov. 198, 26. 5. 1960. Nekoliko dana prije izdana je naredba za formiranje obavještajnih centara II. uprave GŠ JNA po sličnom principu. Na teritoriju NR Hrvatske bili su u Zagrebu, Rijeci, Splitu i Osijeku. SR-VA-VBA, kut. 32, 7.1.01, sveska br. 3, 48 i sveska br. 4, 187. 
Neka iskustva reorganizacije Jugoslavenske narodne armije prema planu „Drvar”

Reorganizacija „Drvar” poklopila se sa zenitom hladnoga rata 1961. 1962., koji je u svjetskim razmjerima bio vidljiv u događajima poput berlinske krize, nastale postavljanjem sovjetskih raketa na Kubi, koji su odnose Sjedinjenih Američkih Država (SAD) i Sovjetskoga Saveza dramatizirali do izbijanja nuklearnoga rata. Sve su to bila neočekivana iskušenja za politički i vojni vrh Titove Jugoslavije.

Štoviše, tijekom reorganizacije prema planu „Drvar”, a u periodu nakon otkazivanja američke vojne pomoći, bilo je uočljivo sve veće zaostajanje u kvaliteti i razini suvremenosti naoružanja kojim je JNA raspolagala. Bez obzira na nove organizacijske forme, vrh JNA uočio je njezino upadljivo tehnološko zaostajanje u odnosu na armije susjednih država koje su bile u Varšavskom ili Sjevernoatlantskom paktu. Dio neophodnih nabavki izvršen je kupovinom sa zaliha američkih vojnih viškova u Europi, ali bila je riječ o tipovima aviona ili tenkova koji su već otprije bili u naoružanju JNA. ${ }^{26}$

Kako nije bilo logično da se od Amerikanaca traži najmodernije naoružanje nakon prekida programa vojne pomoći, a dolazilo je do sve većega približavanja Sovjetskom Savezu i zemljama istočnoga bloka, tako će se vojni vrh okrenuti nabavkama na toj strani. Od 1961. započet će intenzivni pregovori sa Sovjetskim Savezom o kupovini tada najmodernijih tipova sovjetskoga naoružanja: modernih tenkova, artiljerije, gusjeničnih vozila, supersoničnih lovaca, promatračkih radara i raketnih sustava za protuzračnu obranu; nešto kasnije i torpednih i raketnih čamaca, kao i opreme i naoružanja za ugradnju na brodove koji su proizvođeni u Jugoslaviji. Dio složenoga naoružanja nabavljat će se poslije i u Čehoslovačkoj i Poljskoj. Tako je od 1962. nastupio novi val modernizacije JNA i njezino ponovno svrstavanje u modernije europske vojske. Novi sistemi i naoružanje utjecat će na slanje pripadnika JNA na tečajeve preobuke ili usavršavanja u Sovjetski Savez, ali i na razvoj i usložnjavanje obrazovnih programa u školskim centrima JNA i produžavanje školovanja aktivnoga sastava.

Okretanje Sovjetskom Savezu utjecat će na odluku SAD-a da obustavi sve daljnje isporuke vojne tehnike i naoružanja za JNA. To je bila posebno otežavajuća okolnost jer je veliki dio naoružanja i tehnike koji je Armija koristila bio američkoga podrijetla, dobiven tijekom 50 -ih godina. Tim zaokretom dolazi do novoga promišljanja obrane, koje se temelji na pretpostavci da je jedini mogući agresor NATO (Grčka, Italija, snage NATO-a iz Zapadne Njemačke), a da to više nisu zemlje Varšavskoga pakta. Na taj način doći će do orijentiranja udarnih snaga prema zapadnim granicama i zapostavljanja razmišljanja o obrani od eventualne agresije vojski Varšavskoga pakta. ${ }^{27}$

26 SR-VA-JNA, zatvorena građa, svežanj 3305, 15.

27 SR-VA-JNA, zatvorena građa, svežanj 3298, 19. 
Već 1961. nabavljeno je prvih dvadeset komada sovjetskih tenkova T-54, a potom 1962. još četrdeset. Tada je izvršeno preoružanje 2. oklopnog puka u Jastrebarskom tim tenkovima. Tijekom te godine počelo je i preformiranje 31. oklopnog puka u Dugom Selu i preoružanje jednom četom tenkova T-54. U provođenju preoružanja tim tenkovima polazilo se od ideje da jedinice na zapadu države, dakle 5. armiju (a prije svega oklopnu diviziju u Sisku), treba naoružati novim tipovima sovjetskih tenkova ${ }^{28}$, ali i drugim sredstvima: samohodnim protuavionskim topovima ZSU-57-2 ili protuoklopnim raketama tipa Šmelj, kao i prvim serijama domaćih oklopnih transportera M-60. ${ }^{29}$

Reorganizacija „Drvar” izvođena je pod dubokim utjecajem očekivanja nuklearnoga rata. To se ogledalo u usitnjavanju jedinica, smanjenju artiljerije i pješadije ukidanjem razina bataljon-divizion i povećanju dijelova za $\mathrm{ABKO}$. Došlo je do svojevrsne decentralizacije oklopnih jedinica i njihove integracije u određene pješadijske jedinice. Smatralo se da jedinice mogu djelovati i samostalno u situacijama kad je izvršen nuklearni napad, pa je u skladu s tim došlo do organizacijskih promjena, a kod jednoga broja jedinica i njihovo prebaziranje u druge garnizone.

Problem koji se javio nakon stupanja na snagu nove organizacije, odnosno formiranja ili premještanja mnogih jedinica, bio je nedostatak ljudstva. Naime, u reorganizaciji je radi popune aktiviran veliki postotak borbenih vozila i tehnike koji je prije bio u konzervaciji. Te su jedinice bile ili „ratne” ili imale smanjeni sastav ljudstva, pa je odjednom iskrsnuo problem manjka ljudstva za popunu. Zbog toga su uvedene i neke izvanredne partije regruta, koje su se obučavale $u$ jedinicama radi što bržega stvaranja mogućnosti da te jedinice zažive i dovedu se u punu bojnu gotovost. ${ }^{30}$

Realizacijom plana „Drvar” korjenito je izmijenjen i način izvođenja vojničke obuke. Sistem da se regruti pozivaju najprije u nastavni centar i u njemu završe šestomjesečnu obuku (1956. - 1959.), a potom upućuju u trupne jedinice pokazao se manjkavim jer je baza za obuku i pažnja prema njima bila nedovoljna, pa su u jedinicama morali nastaviti s obukom vojnika. Novi planovi obuke za vojnike prilagođeni su ideji vođenja „savremenog budućeg ONOR-a baziranog na našim uslovima i materijalnim mogućnostima" i stupili su na snagu 1. lipnja 1959. godine. Primjetno je da su pojačani sadržaji iz obuke u uvjetima nuklearnoga rata. Po završetku obvezne obuke predviđeno je da se daljnja obuka vojnika izvodi prema mogućnostima svake jedinice. ${ }^{31}$

Mnoga od rješenja u kopnenoj vojsci JNA nisu odgovarala mogućnostima ili prijašnjoj praksi, koja je teško prihvaćala izmjene. Petorna formacija zaživjela je tek u dijelu jedinica. Doslovno je primijenjena „na papiru” samo za ratne (dakle nepostojeće) jedinice. U realnosti je došlo do niza odstupanja prelaskom sa standardne „trojne” formacije na ovakvu s pet jedinica. Neke

\footnotetext{
28 SR-VA-JNA, zatvorena građa, svežanj 3293, 23; SR-VA-JNA, kut. 438, fasc. 4, d. 1-74.

29 SR-VA-JNA, zatvorena građa, svežanj 3279, 13-18; SR-VA-JNA, kut. 438, fasc. 4, d. 1-74.

30 SR-VA-JNA, kut. 438, fasc. 4, d. 1.

31 SR-VA-JNA, kut. 438, fasc. 1, d. 1.
} 
su divizije imale pet, a neke su (kao 6. lička i 19. dalmatinska) ostale sa po tri puka. Oklopna divizija imala je samo tri oklopna puka, nastala preformiranjem dviju brigada, a samostalna oklopna brigada četiri umjesto pet tenkovskih četa.

U udarnom vidu JNA, zrakoplovstvu, osnovni problemi nastali preformacijom „Drvar” bili su mnogobrojni. Uvidjelo se već 1961./1962. da je organizacija s pet zrakoplovnih komandi preglomazna, neekonomična i nesvrsishodna. Neke su komande bile popunjene i preko formacije, a neke su imale samo nekoliko jedinica. Teritorij rascjepkan na vak-ove otežavao je integraciju PVO-a, ali i usitnjavao eventualnu zrakoplovnu podršku snagama kopnene vojske. Za slučaj rata u takvoj situaciji krupnije operacije morala bi preuzimati Komanda RV i PVO, a neke zrakoplovne komande tijekom rata bile bi potpuno izvan funkcije zbog očekivanih gubitaka u teritoriju, pa bi njihove komandne nadležnosti morale preuzimati druge odnosno preostale komande. Preformacija je izazvala dosta problema u RV i PVO, o čemu govori i konstatacija da je „osposobljenost vazduhoplovnih komandi i štabova na prosečnom nivou. Velike izmene u koncepcijama, izmene u organizaciji i nameni pojedinih komandnih stepena uticali su na njihovu sposobnost. Objektivne teškoće su takođe bile velike jer još nisu bila gotova osnovna pravila prema kojima bi se te komande rukovodile i obučavale". ${ }^{32}$

Kad se rezimira period od sredine 1959. do 1964., možemo ocijeniti da su preformacijom „Drvar” nastali brojni problemi. Mnoga od primijenjenih rješenja bila su u skladu s vremenom ili praksom u drugim vojskama, ali su tehnološke, kadrovske i druge mogućnosti JNA bile ograničavajući faktor, pa stoga i činilac za vraćanje na neka od starih rješenja od prije 1959. godine.

\section{Reorganizacija prema planu „Drvar 2” 1964. godine}

Već od 1963. intenzivno se radilo na novoj organizaciji JNA, odnosno na ispravljanju pojedinih rješenja uvedenih planom "Drvar”. ${ }^{33}$ Novi plan reorganizacije donesen 1964., poznat kao „Drvar 2”, obuhvaćao je kao i „Drvar” promjene u organizaciji, formaciji i dislokaciji jedinica JNA i ustvari je bio korekcija prethodnoga plana, iako se to poslije često predstavljalo kao nastavljanje reorganizacije da se ne bi nikoga posebno apostrofiralo za greške i pogrešna organizacijska rješenja. Reorganizacija JNA „Drvar 2” naređena je 8. srpnja 1964. godine. ${ }^{34}$ Taj plan također je „zavrtio” mnoge jedinice na terenu, donio niz novih rješenja, novih ili starih organizacijskih formi.

32 SR-MJRV-RVPVO, Istorijat Komande JRV za 1962. i 1964. godinu.

33 SR-VA-JNA, zatvorena građa, svežanj 3295, 14 (Naredba I uprava GŠ JNA, str. pov. 283, 25. 12. 1962.).

34 SR-MO-SLJR-UO, Nar. DSNO, str. pov. 154, 8. 7. 1964. i Nar. III uprave, str. pov. 215, 12. 5. 1964. 
Najprije su sredinom 1964. reorganizirane granične jedinice. U sastavu graničnih brigada ukinuti su bataljoni, a brigade su prešle na četni sastav. Broj četa u brigadi ovisio je o širini njezina graničnoga odsjeka, a broj ljudi u četi o procjeni svakoga dijela granične fronte - odsjeka i svakoga pravca. Nakon reorganizacije i ukidanja graničnih bataljona, granične jedinice u Socijalističkoj Republici (SR) Hrvatskoj bile su 199. granična brigada u Podravskoj Slatini s pet četa i 31. granična mornarička brigada sastavljena od tri granična mornarička odreda. ${ }^{35}$

Zatim se prešlo na reorganizaciju jedinica kopnene vojske. Najprije su izvedene izmjene u divizijama i pukovima, a potom u vojnim područjima i armijama. Nove formacije za jedinice kopnene vojske stupile su na snagu 15. rujna 1964. godine.

Zagrebačka 5. armija preformirana je (ponovo) u 5. armijsku oblast (komandant general-potpukovnik Ivan Rukavina), koja bi u ratu razvijala 5 . armiju. Teritorijalna nadležnost nije promijenjena osim što je od 7. armije preuzet garnizon Virovitica s tamošnjim 7. proleterskim pukom. U sastav 5. armijske oblasti ulazila su sljedeća vojna područja: Zagreb, Rijeka i Ljubljana. Ona su u ratnoj formaciji sada razvijala korpuse.

Kako se „petorna” formacija iz 1959. pokazala kao teško primjenjiva u JNA zbog niza manjkavosti, u reorganizaciji „Drvar 2” opet je vraćena standardna „trojna” formacija u pješadijskim jedinicama, a vraćena je i prethodno ukinuta organizacijska razina bataljona. Tako su pješadijske divizije ponovo u svojem sastavu imale po tri pješadijska puka i sve druge jedinice rodova kopnene vojske (artiljerijski puk, tenkovski bataljon - pojedine divizije, inženjerijski i bataljon veze, artiljerijsko-raketne i jedinice ABKO). Pješadijski su pukovi umjesto četne ponovo uspostavili bataljonsku formaciju. Tako su nakon pet godina definitivno prestali postojati „pentomik” pješadijski pukovi i divizije u kopnenoj vojsci JNA.

U 5. armijskoj oblasti s pet na tri pješadijska puka preformirane su 6. proleterska divizija u Karlovcu i 14. proleterska divizija u Varaždinu, uz unutrašnju izmjenu jedinica u obje divizije. Tri pješadijske divizije tipa B, 13., 32. i 35. , sad su postale samostalni pješadijski pukovi jer su ustvari jačinom od pet četa to i bile. ${ }^{36}$

Oklopna divizija u Sisku umjesto pukova ponovo je imala oklopne brigade (2. Jastrebarsko, 31. Dugo Selo i 265. Bjelovar, ali sve tri i dalje samo sa po dva oklopna bataljona, kao i 1945. - 1959.). Još jedno bitno opredjeljenje ove organizacije bilo je uvođenje oklopnih pukova u sastave pojedinih pješadijskih divizija (u 5. armiji kod 14. divizije). Ti pukovi s dva oklopna bataljona i pratećim jedinicama nisu bili osposobljeni za samostalna djelovanja, nego su trebali biti podrška snagama divizije. Drugi dio divizija i nekoliko pješadijskih

35 SR-MO-SLJR-UO, Nar. DSNO, str. pov. 126, 15. 4. 1964.

36 SR-MO-SLJR-UO, Nar. III uprave, str. pov. 215, 12. 5. 1964.; Razvoj OS SFRJ, knj. 3: Kopnena vojska JNA, tom I, 113-116. 
brigada imali su oklopne bataljone u svojem sastavu. Ovom reorganizacijom pojačane su oklopne jedinice u 5. vojnoj oblasti. Tenkovi su 1964. standardizirani po oblastima: u 5. vojnoj oblasti bila su dva najsuvremenija tipa, sovjetski T-54 i američki M-47 Patton, kao i M4A3 Sherman u ratnim jedinicama. Već 1964. primljeni su najsuvremeniji sovjetski tenkovi T-55 u sastav brigade u Bjelovaru, potom iduće godine i u Dugom Selu. ${ }^{37}$

U domeni ratne vojske, na području cijele 5. oblasti preformirano je 26 partizanskih brigada u "grupe za razvoj” i formirano još 13 novih takvih jedinica. Četiri takve komande su ukinute, a teritorijalni odredi preformirani su u teritorijalne bataljone. Prema ovoj reorganizaciji, na teritoriju SR Hrvatske 14 pukova tipa B je rasformirano, a dva su postala grupe za razvoj dopunskih pukova $\mathrm{R}$.

Od jedinica baziranih u SR Hrvatskoj, a bile su u sastavu 7. armije, 12. (slavonska) pješadijska divizija prešla je u Slavonsku Požegu i preformirana je u formaciju od tri pješadijska puka. Na prostoru SR Hrvatske rasformirano je pet komandi pješadijskih pukova tipa B. Bez promjena su bili garnizoni u Đakovu (158. protuoklopna brigada), a izvršene su neke manje promjene u inženjerijskim jedinicama u Slavonskom Brodu i rasformirane manje jedinice veze u Slavonskoj Požegi. Početkom 1965. rasformirano je vojno područje u Slavonskoj Požegi, ali je formirano vojno područje u Osijeku zbog „izvesnih izmena u proceni strategijske situacije". ${ }^{38}$

Reorganizacijom „Drvar 2” netipične jedinice „objekti PVO” ponovo su preformirane u pukove ili divizione od kojih su nastale. Za obranu grada Zagreba formirana je od protuavionskih jedinica veća jedinica: 5. zona PVO. ${ }^{39}$

U 4. armiji - sada armijskoj oblasti (komandant general-pukovnik Miloš Šumonja) napravljene su sljedeće promjene: u mornaričkim jedinicama najvažnije su bile preformiranje Vojnopomorskoga područja Pula u vojnopomorski sektor, 1. flotile u komandu 1. eskadre u Splitu i ukidanje dijela plovnih jedinica u vojnopomorskim sektorima.

Prva eskadra, kao najveća plovna jedinica, bila je sastavljena od sljedećih flotila: 11. torpednih čamaca u Splitu, 38. patrolnih brodova u Kumboru i 16. minolovaca u Pločama, te 4 . diviziona razarača u Splitu i novoformiranog 88. podmornica u Puli. Na taj način prestala je svojevrsna razbijenost plovnih jedinica po područjima i sve udarne plovne snage ponovo su objedinjene $u$ eskadru, kao i 1953. - 1959. godine. Zbog starosti brodova ukinut je 6. divizion razarača. Ipak, dio pomoćnih plovnih sredstava zadržan je na razini vojnopomorskih sektora: pomoćni brodovi i minopolagači, a u sva tri sektora u ratu se od civilnih - popisnih brodova formiraju divizioni pomoćnih minolovaca (minopolagača). Od drugih mornaričkih jedinica formirani su i 82. pomorski centar (ronilački), a od rasformiranoga 85. bataljona obalske službe

37 SR-VA-JNA, zatvorena građa, svežanj 3298, 8, svežanj 3297, 1-15 i svežanj 3299, 2; SR-

VA-JNA, kut. 438, fasc. 4, d. 1-74 (Uprava OJ, str. pov. 125, 26. 6. 1963.).

38 SR-MO-SLJR-UO, Nar. III uprave, str. pov. 215, 12. 5. 1964.

39 SR-MJRV-RVPVO, Istorijat Komande JRV za 1964. godinu; Razvoj OS SFRJ, knj. 3: Kopnena vojska JNA, tom II, 443. 
osmatranja i javljanja (OSOJ) ostala je četa s komandom u Splitu i jedinicama za motrenje na Muzilu, Brijunima, Premudi i u Malom Lošinju. Napravljen je manji dio promjena u obalnoj artiljeriji. ${ }^{40}$

U Kninu je 19. dalmatinska pješadijska divizija A preformirana u 91. pješadijsku brigadu, a 9. dalmatinska pješadijska divizija B u 9. pješadijski puk, u Dubrovniku je 472. mornaričko-desantna brigada preformirana u bataljon. Rasformirane su tri komande pješadijskih pukova $B$, a jedna je preformirana. Objekti PVO-a preformirani su u pukove (Split) ili baterije (Split, Vis, Ploče), a inženjerijski puk u Sinju preformiran je u četu. Manje promjene izvedene su i u drugim jedinicama rodova kopnene vojske. ${ }^{41}$

U zrakoplovstvu je od jedinica 5. i dijelova 7. i 9. vak-a u lipnju 1964. formiran 5. vazduhoplovni korpus (komandant general-potpukovnik Viktor Bubanj) s komandom u Zagrebu, koji je u nadležnosti imao cjelokupnu zapadnu polovinu Jugoslavije. U njegovoj nadležnosti bili su aerodromi, odnosno zrakoplovne baze: Cerklje, Pleso, Zemunik, Rajlovac, Pula i novi aerodrom kod Bihaća, koji je bio u izgradnji; zatim avijacijski pukovi: 97. u Mostaru, 109. u Cerklju, 111. i 184. na Plesu, 172. u Zemuniku, a u ratnoj formaciji i dva puka Vazduhoplovne vojne akademije, 105. u Zemuniku i 185. u Puli. Tom reorganizacijom 1964. u Zagreb iz Niša prelazi 780. transportna helikopterska eskadrila s helikopterima Mi-4. Njezin ulazak u sastav 5. vazduhoplovnog korpusa označit će novu stranicu u stvaranju zračne podrške snagama kopnene vojske 5. armijske oblasti. Iste godine formira se u Mostaru (poslije prelazi u Divulje) i 784. protupodmornička helikopterska eskadrila s helikopterima S-55 za podršku snagama Ratne mornarice. Uvođenjem helikoptera kopnena vojska i mornarica dobivaju prve elemente zračne pokretljivosti. ${ }^{42}$

Jedinice zračnoga motrenja, javljanja i navođenja (vazdušnoga osmatranja, javljanja i navođenja - VOJIN) u okviru 5. korpusa sad objedinjava 5. puk VOJIN. U sastav puka u prethodnim godinama ušli su i sovjetski radari tipa P-30, postavljeni na položaje Kurilovec, Pula i Ljubljana. Ostali radari u upotrebi bili su stariji, američkoga tipa. ${ }^{43}$

Važan korak u reorganizaciji „Drvar 2” bilo je skraćivanje vojnoga roka sa 24 na 18 mjeseci. Vojni rok sada je uključivao pet dana prilagođavanja na vojnički život, potom je počinjala faza opće obuke od 40 dana, slijedilo je pet mjeseci stručne obuke i tri mjeseca zajedničke obuke. Nastavni sadržaji obuke također su izmijenjeni. Povećani su sadržaji fizičke, kondicijske obuke, udio bojevih gađanja, uvedene određene teme shodno dominantnim stavovima o očekivanom nuklearnom ratu i proširena obuka u različitim klimatskim, terenskim i vremenskim uvjetima. Uvođenjem nove tehnike i naoružanja razvijena je i materijalna baza obuke, a vojnici su uključeni u obuku i upotrebu

40 SR-MO-SLJR-UO, Nar. III uprave, str. pov. 215, 12. 5. 1964.; Razvoj OS SFRJ, knj. 5: Ratna mornarica, 102.

${ }^{41}$ SR-MO-SLJR-UO, Nar. III uprave, str. pov. 215, 12. 5. 1964.

42 SR-MJRV-RVPVO, Istorijat Komande JRV za 1964. godinu.

43 BOŠKOVIĆ, Nebo na dlanu, 175, 197-202. 
najsuvremenijih sredstava. Time se težilo podizanju borbenih sposobnosti aktivnoga ljudstva u Armiji. ${ }^{44}$

Ipak, nove promjene u operativno-teritorijalnim komandama utjecale su na znatna premještanja kadrova i promjene u planovima upotrebe jedinica. Organizacijske promjene uvjetovale su i umirovljenje oko 10000 oficira kopnene vojske (od 1964. do 1967.), od kojih su dvije trećine bili mlađi od 45 godina! ${ }^{45}$ Umirovljeni su uglavnom zato što su imali manjak vojno-školske spreme, pa su lako mogli biti označeni kao višak ili neperspektivni kadrovi. Dio njih nije pristajao na prelazak u udaljene garnizone, a razvoj nekih civilnih poduzeća (primjerice aerotransportne kompanije) omogućio je prelazak u civilni život i rad na bolje plaćenim mjestima.

\section{Preimenovanje prema partizanskim tradicijama i novi plan „Snaga”}

Godine 1965. dogodit će se nova izmjena u jedinicama kopnene vojske JNA. Došlo je do opsežnoga preimenovanja znatnoga dijela pješadijskih i združenih jedinica JNA, i to zbog prilagođavanja mirnodopskih partizanskim tradicijama. Naredbom od 3. srpnja 1965. u domeni ratnih tradicija jedinica JNA (korpus - divizija - brigada/puk) učinjena je radikalna promjena. ${ }^{46}$ Provedena je prenumeracija jedinica i dodjeljivanje tradicija partizanskih jedinica (iz takozvanoga Narodnooslobodilačkog rata) prema regionalnom tipu, sve u skladu s idejom da jedinice JNA na jednom prostoru nastavljaju tradicije lokalnih partizanskih jedinica iz Drugoga svjetskog rata. U dijelu jedinica izmijenjene su samo tradicije, koje su naredbom određene bez obzira na prethodnu povijesnu liniju jedinica, koja je mogla biti slavnija od novododijeljene „tradicije”. Ali bilo je i znatnoga preimenovanja jedinica u skladu s ovom idejom. Tako tradicijski utemeljene, te imenovane jedinice mahom će ostati s istim nazivima do 1991. godine.

Shodno toj ideji preimenovane su i neke elitne jedinice bazirane u SR Hrvatskoj, kao što je bila 14. proleterska divizija u Varaždinu, sada preimenovana u 8. pješadijsku diviziju (broj kao kod partizanske 8. kordunaške), odnosno njezini 11., 14. i 16. proleterski puk postali su 140., 73. i 145. pješadijski puk, a njihova imena preuzele su druge jedinice. Novi pukovi nastavljali su tradicije hrvatskih partizanskih brigada. Jedina preostala oklopna divizija (20.) u Sisku preimenovana je u 7. (po ugledu na 7. banijsku iz rata). Nepreimenovana divizija ostala je karlovačka 6. proleterska pješadijska, koja se uklapala u ovaj trend prilagođavanja tradicija jer je od rata zadržala isti naziv. Na drugoj strani neke „obične” jedinice postale su proleterske: kninska 91. brigada - sada 11. proleterska (1. dalmatinska), odnosno riječka 25. brigada - sada 13. proleterska (isti naziv kao i partizanska - hrvatska brigada).

44 Razvoj OS SFRJ, knj. 3: Kopnena vojska JNA, tom I, 134-137.

45 Isto, 114.

46 SR-MO-SLJR-UO, Nar. DSNO, str. pov. 319, 3. 7. 1965. 
Preimenovane su i komande ratnih korpusa u istoj maniri: zagrebački 4. postao je 10., a riječki 7. preimenovan u 4., oba nazvana prema partizanskim korpusima. Uvedeni su novi nazivi za ratne partizanske brigade koje su dotad nosile naziv mjesta (npr. Riječka, Bjelovarska itd.), a sada su nosile broj i regionalno određenje. ${ }^{47}$

Mnogo je motiva sigurno bilo presudno za taj projekt, prije svega ideoloških. Svakako je tu bila i potreba da se jedinice, odnosno stanovništvo i lokalne institucije identificiraju kroz tradicije jedinica formiranih $\mathrm{u}$ ratu na jednom prostoru, odnosno jedinice koje će nastavljati njihovu tradiciju.

Već 1966. na organizacijske promjene u okviru plana „Drvar 2” (1964.) i izmjene naziva jedinica shodno partizanskim tradicijama (1965.) nadovezale su se promjene prema novom planu, nazvanom „Snaga”. Te organizacijske promjene izvedene su 1966. - 1968. i značile su u suštini daljnje smanjenje brojnoga stanja JNA prema očekivanjima da Jugoslaviji s Istoka više ne prijeti nikakva vojna opasnost.

Naredba za izradu toga plana datirana je sa 11. srpnja 1964., a radilo se o „planu perspektivnog razvoja naših oružanih snaga”, koji je od 22. veljače 1965. „šifrovan tajnim nazivom: Snaga”. Plan nove organizacije i rasporeda jedinica JNA bio je projektiran s osloncem na plan i tijek preoružanja sovjetskom tehnikom. Plan je trebao biti proveden do 1970., s tim da je realizacija plana od $90 \%$ bila predviđena zaključno sa 1968. godinom. Jedan je događaj posebno utjecao na atmosferu oko njegove izrade. Naime, u jednom njemačkom časopisu (ime se ne navodi) objavljen je članak o organizaciji JNA s procjenama „približno identičnim projektovanim promenama u okviru plana Snaga”. Zbog toga je Uprava sigurnosti Državnoga sekretarijata za poslove narodne obrane (DSNO) zahtijevala analizu curenja podataka i najviše mjere sigurnosti od svih dijelova sistema koji su sudjelovali u izradi plana. ${ }^{48}$

Promjene u zrakoplovstvu svakako su bile najkarakterističnije za plan „Snaga” iz 1966. godine. Radi podrške kopnenoj vojsci bit će formirana jedna (82.) avijacijska brigada u Cerklju, a 1968. i jedna za podršku mornarici (97.) u Mostaru, s jedinicama u Divuljama i Zemuniku. Ta 97. brigada potom će biti izdvojena iz sastava 5. vazduhoplovnoga korpusa i izravno podređena Komandi RV i PVO sve do sredine 80 -ih godina. ${ }^{49}$

U sistemu protuzračne odbrane, zone PVO-a, s kojima su komande dvaju zrakoplovnih korpusa imale problema u neprecizno reguliranim odnosima i nadležnostima, planom „Snaga” preformirane su u divizije PVO-a, koje su

47 Naziv hrvatska partizanska dobile su sljedeće brigade: 1. (Samobor), 2. (Sesvete), 4. (Vrginmost), 5. (Križevci), 6. (Varaždin), 7. (Krapina) i 36. (Delnice). Potom slijede regionalni nazivi: 16. banijska (Sisak); moslavačka: 1. (Bjelovar) i 2. (Kutina); slavonska 5. i 21.; primorsko-goranska: 3. (Crikvenica) i 4. (Rijeka); kordunaška: 15. (Ogulin), 16. (Karlovac) i 31. (Plaški); lička: 1. (Gospić) i 36. (Otočac); istarska: 2. (Pazin) i 3. (Labin); dalmatinska: 6. (Benkovac), 9. (Split), 10. (Sinj) i 12. (Knin). SR-MO-SLJR-UO, Nar. DSNO, str. pov. 319, 3. 7. 1965.

48 SR-VA-JNA, zatvorena građa, svežanj 4555, 42 i svežanj 4551, 2.

49 SR-MO-SLJR-UO, Nar. DSNO, str. pov. 63, 17. 2. 1966. i str. pov. 730, 19. 12. 1968. 
sada bile na izravnoj vezi zrakoplovnih korpusa. Nastale su 11. divizija u Beogradu i 15. divizija u Zagrebu, svaka odgovorna za polovinu državnoga teritorija. U njihov sastav ušle su jedinice lovačke avijacije, raketne, radarske i protuavionske jedinice. Suština tih izmjena bilo je stvaranje dvaju zaokruženih borbenih sistema: jedan za zračnu podršku kopnenoj vojsci, a drugi za protuzračnu obranu. ${ }^{50}$ Organizacijski model ovdje je preuzet iz sovjetske prakse.

No zagrebačka 15. divizija PVO popunjavala se mnogo sporije zbog isporuka sovjetske tehnike koje će se produžiti sve do ljeta 1968. godine. Naime, dio jedinica bio je opremljen starijom američkom tehnikom i čekale su se isporuke sistema PVO-a iz Sovjetskoga Saveza. Tako je još sredinom 1965. izrađena formacija 155. raketnog puka PVO, čije će formiranje uslijediti 1967. godine. Tek je te godine puk opremljen protuavionskim raketnim sistemom S-75M Volhov i raspoređen u širem rajonu Zagreba s raketnim položajima kod Karlovca, Siska i Cerklja. ${ }^{51}$

Iste 1967. godine u naoružanje 5. puka VOJIN ulaze novi sovjetski radari: promatrački P-12 kao i visinski PRV-11 i radarski komplet P-35. Za operativni centar 5. puka VOJIN, koji je ujedno bio komandno mjesto 15. divizije PVO, izgrađen je podzemni objekt Buševec, koji je počeo s radom 1968. (na samom početku „čehoslovačke krize”). ${ }^{52}$

Ulazak sovjetskoga supersoničnog lovca MiG-21F u sastav jugoslavenskoga zrakoplovstva 1962. bio je impuls za modernizaciju lovačke avijacije i razvoj sistema protuzračne obrane. Isporuke toga tipa trajale su do 1965., a potom novije verzije MiG-21PFM u periodu 1967. - 1968. Tek je tada bilo moguće zagrebački 117. lovački puk opremiti tim tipom lovca. Po završetku preobuke jedne eskadrile (125.) iz sastava puka piloti su prelijetali migove iz Batajnice na aerodrom Pleso u listopadu 1967. godine. Međutim, u svibnju 1968. naređeno je i provedeno prebaziranje 117. lovačkog puka na novoizgrađeni podzemni aerodrom u Bihaću. Prebaziranje iz Zagreba donijelo je niz personalnih problema: dio starješina hrvatske i slovenske nacionalnosti napustio je vojsku ne želeći se seliti u taj udaljeni garnizon..$^{53}$

U kopnenoj vojsci tijekom 1966. formirane su dvije partizanske divizije: 43. istarska u Pazinu i 34. u Delnicama, ali je istom naredbom rasformirano još nekoliko partizanskih brigada. ${ }^{54}$ Tijekom ljeta 1967. preformirana je komanda 7. oklopne divizije u Sisku, a i neke oklopne jedinice (formirani su oklopni pukovi u Varaždinu, Karlovcu i Osijeku). Obrana Istre posebno je ojačana kad je iz Maribora prebačena 209. pješadijska brigada, koja je prešla u Pulu i preimenovana u 25. pješadijsku brigadu. Ta jedinica zauzela je garnizo-

50 SR-MJRV-RVPVO, kut. 25, Istorija 11. dPVO 1965-1984 (dokument uključuje i historiju 1. zone PVO do preformiranja u 11. dPVO 1966.).

51 SR-MJRV-RVPVO, kut. 112, „Formiranje i preformiranje jedinica RV, u 1967. godini”, 3; Razvoj OS SFRJ, knj. 3: Kopnena vojska JNA, tom II, 443.

52 BOŠKOVIĆ, Nebo na dlanu, 197-201.

53 SR-MJRV-RVPVO, kut. 31, Istorijat 117. lovačkog puka za 1967. i 1968

54 SR-MO-SLJR-UO, Nar. DSNO, str. pov. 324, 25. 7. 1966. 
ne širom Istre: u Umagu, Lovranu i Pazinu. Za obranu Brijuna formiran je te jeseni 38. gardijski objekt PVO. ${ }^{55}$

Pored niza reorganizacija u kojima se ogleda želja vojnoga vrha da objedini efektive kopnene vojske i pomorskih snaga, 60-e su bile godine u kojima su se postavljali temelji za modernizaciju flote. Podmornice dobivaju na važnosti, a u perspektivi se očekivao daljnji razvoj njihove proizvodnje u domaćim brodogradilištima. U preformaciji iz 1964. i Podmornička komanda preformirana je u 88. divizion podmornica, koji je i dalje bio sastavljen od samo tri podmornice, od kojih je jedna korištena za obuku. U periodu 1966. - 1967. rasformirana je Podmornička baza u Puli, a formiran je Pomorski odred za spašavanje u Šibeniku. ${ }^{56}$ Tek je 1968. preuzeta prva od serije triju novih podmornica domaće izrade. Bila je to podmornica „Heroj”. Ostale dvije primljene su 1970. godine. ${ }^{57}$

Prekretnica u opremanju JRM-a nastupa 1965., kad je u Jugoslaviju iz Sovjetskoga Saveza stigao prvi moderni torpedni čamac tipa Shershen. Čamac je dobio broj 211 i prema njemu će se poslije izraditi serija od ukupno deset čamaca u „Titovu brodogradilištu” u Kraljevici. Sa sovjetskim čamcima ukupno će ih biti 14 komada u naoružanju. Uz taj tip nabavljena je i veća količina od 160 sovjetskih torpeda. Iz Sovjetskoga Saveza u tom periodu nabavljeno je i deset raketnih čamaca tipa Osa. Prvi je primljen 1965., potom 1966. još jedan, a sukcesivno sve do kraja 1969. preuzeto je svih deset takvih čamaca i formirana flotila. S tim tipom u sastav JRM-a uvode se i prve vođene rakete more-more tipa P-15, koje su nabavljene u količini od 96 komada.

U tom periodu iz domaćih brodogradilišta stizali su patrolni/granični čamci, pomoćni brodovi (šest), jedan hidrografski brod i druga oprema. U flotnu listu primljena su početkom 60-ih dva (velika) patrolna broda tipa PBR-551 i 552, koji su izrađeni u „Titovu brodogradilištu”. Uglavnom, težište se okrenulo izradi većega broja manjih patrolnih/graničnih čamaca, a to su bili patrolni čamci tipa PČ-132 (pet) i PČ-137 (četiri), koji su ušli u naoružanje u drugoj polovini 60 -ih godina. ${ }^{58}$

\section{Vojno školstvo na prostoru Socijalističke Republike Hrvatske}

Dio škola i školskih jedinica JNA bio je smješten na prostoru NR/SR Hrvatske još od završetka Drugoga svjetskog rata, koristeći bazu škola još iz vremena Austro-Ugarske, Kraljevine Srba, Hrvata i Slovenaca / Jugoslavije ili Nezavisne Države Hrvatske. To su bile mornaričke i pojedine škole rodova kopnene vojske: artiljerije, inženjerije, protuavionske artiljerije i tehničkih službi. Zrakoplovne škole stići će tek početkom 60-ih.

55 SR-MO-SLJR-UO, Nar. DSNO, str. pov. 231, 12. 6. 1967., str. pov. 443, 25. 9. 1967. i str. pov. 462, 5. 10. 1967.

56 SR-MO-SLJR-UO, Nar. DSNO, str. pov. 370, 31. 8. 1966. i str. pov. 68, 27. 3. 1967.

57 KOMAR, Podmorničarstvo Jugoslavije, 99-119.

58 Razvoj OS SFRJ, knj. 5: Ratna mornarica, 87-95. 
Inženjerijski školski centar u Karlovcu imao je 1961. u svojem sastavu organizirane cjeline: Inženjerijsku školu za usavršavanje, Inženjerijsku podoficirsku školu, Školu za rezervne inženjerijske oficire, 513. (školski) inženjerijski puk i druge manje dijelove za opsluživanje rada. U načelu je ta struktura ostala i nakon reorganizacije JNA „Drvar 2” 1964., iako su imena škola u sastavu Centra donekle izmijenjena. ${ }^{59}$

Još od 1956. u Zadru se formira Artiljerijski školski centar, koji objedinjava rad artiljerijskih škola: podoficirske škole, škole rezervnih oficira i motoškole, a jedno kratko vrijeme iste godine i škole protuavionske artiljerije. Druga škola-centar bila je u Zagrebu još od 1945. godine. Po novoj reorganizaciji iz 1961. Artiljerijska škola za usavršavanje oficira u Zagrebu mijenja naziv u Škola za usavršavanje artiljerijskih oficira. Ostalo školovanje za rod artiljerije (podoficiri, rezervni oficiri i usavršavanje oficira preko tečajeva) u tom periodu izvodilo se u Artiljerijskom školskom centru u Zadru. U sljedećoj reorganizaciji 1964. 1966. artiljerijska škola iz Zagreba prešla je 1964. u Sarajevo. Prijašnja škola za obuku vozača u artiljeriji preformirana je u poseban 557. artiljerijski nastavni centar za obuku vozača, koji je 1968. iz Zadra prebačen u garnizon Benkovac. ${ }^{60}$

U Zadru se od 1947. do 1953. nalazila Protuavionska škola. Godine 1956. formira se ponovo Protuavionski školski centar u Zadru jer je uočeno da je školovanje i usavršavanje oficira protuavionske artiljerije u artiljerijskim školama neodgovarajuće. U skladu s promjenama u protuzračnoj obrani i usložnjavanjem školovanja 1964. Školski centar protuavionske artiljerije preimenuje se u Školski centar PVO. Od školske godine 1966./1967. počela je s radom Vojna akademija PVO, koja je iste školske godine primila prvu klasu pitomaca u svoj sastav. ${ }^{61}$

Stvaranjem Tehničke službe JNA bilo je očito da je potrebno formirati ustanovu za jedinstvenu obuku njezinih pripadnika. Tako se 1953. formira Tehnički školski centar u Zagrebu u vojarnama na Črnomercu. U Centar su ušli prijašnja artiljerijsko-tehnička oficirska škola i automobilski školski centar. Tijekom 50 ih i 60-ih Centar se proširio i na sadržaje drugih rodova i službi. Centar je do 1991. ostao glavno središte za obuku starješina tehničkih službi.

Još od 1947., pa tako i tijekom 60-ih, mornarički oficiri školovani su u Vojnopomorskoj akademiji u Divuljama. Od 1949. ondje je formirana i Viša vojnopomorska akademija. U Divuljama je u okviru Vojnopomorskoga školskog centra 1956. formirana Vojnopomorska podoficirska škola, koja je nastala od Brodarske podoficirske škole, a Viša vojnopomorska akademija preseljena je iz Divulja u Split i postala je samostalna ustanova Komanda Ratne mornarice. Ona je nakon osam godina 1964. vraćena u okvir istoga centra u Divulje. ${ }^{62}$

59 Razvoj OS SFRJ, knj. 3: Kopnena vojska JNA, tom III, 98-100.

60 Razvoj OS SFRJ, knj. 3: Kopnena vojska JNA, tom II, 329-337.

61 Trideset godina Školskog centra PVO, 7-16; Razvoj OS SFRJ, knj. 3: Kopnena vojska JNA, tom II, 453-461.

62 PRIBILOVIĆ, „Uz četrdesetogodišnjicu početka rada Vojnopomorskog učilišta JRM”, 854-862. 
Mornaričko tehničko ljudstvo obučavalo se otprije u Puli. Godine 1961. bit će u sastavu Mornaričkoga školskog centra za specijalizaciju u Puli. Sredinom 60-ih događaju se još neke manje izmjene u mornaričkom školstvu: 1964. ukinut je Mornarički školski centar za specijalizaciju u Puli. Njegove aktivnosti preuzela je novoformirana Škola za usavršavanje i specijalizaciju u sastavu Vojnopomorskoga školskog centra u Divuljama od 1965. godine. Ta škola preuzela je školovanje od tri rasformirane škole za specijalističko školovanje (artiljerijska, podvodnoga oružja i veze), koje su također rasformirane 1964. godine. U toj školi održavani su jednogodišnji tečajevi za usavršavanje mornaričkih tehničkih, a od 1966. i pomorskih oficira. Od školske godine 1966./1967. školovanje pitomaca na Vojnopomorskoj akademiji produženo je s tri na četiri godine. Sljedeće školske godine isto je učinjeno i na Mornaričkoj tehničkoj akademiji. ${ }^{63}$

Obuka mornara za potrebe JRM-a od sredine 1961. počela se izvoditi u novoformiranom Mornaričkom nastavnom centru u Puli, s jednim nastavnim bataljonom i u Lovranu. Centar je bio jedinstvena ustanova za obuku mornara-regruta koji su potom služili u jedinicama mornarice na brodovima i kopnu. Taj sistem obuke vojnika ostat će sve do 1991. godine.

Reorganizacija „Drvar” nije odmah zahvatila zrakoplovne škole, koje su bile previđene za reorganizaciju 1960. godine. U Mostaru je formirana uprava Vazduholovne vojne akademije, koja je zatim prebazirana u Zemunik. ${ }^{64}$ Tako se pored postojećih škola za oficire na teritoriju SR Hrvatske našla i zrakoplovna.

Jugoslavenska narodna armija u društveno-političkom ambijentu sredinom 60 -ih godina

S političke strane JNA je i tijekom 60-ih jačala svoju ulogu u društvu, ali je u suštini bila isključivo vezana za vrhovnoga komandanta i predsjednika Socijalističke Federativne Republike Jugoslavije (SFRJ) maršala Josipa Broza Tita. Sva vjernost vojnoga sastava bila je rezervirana u prvom redu za njega, a tek potom za domovinu i narode vezane politikom „bratstva i jedinstva”. U vojno-partijskom vrhu uočeno je da starješinski kadar ne odražava nacionalnu ili republičku zastupljenost u „civilstvu”, da je nedostajalo polaznika vojnih škola i akademija iz redova hrvatskoga i slovenskoga naroda, kao i iz dijela nacionalnih manjina.

Negativne konotacije valova različitih reorganizacija, a iz toga preseljenja ili umirovljenja sa znatno manjim vojnim mirovinama u odnosu na plaće ak-

${ }_{63}$ Razvoj OS SFRJ, knj. 10: Vojno školstvo JNA, 118-164.

${ }^{64} \mathrm{U}$ sastavu ove nove školske ustanove obnovljeni su 1. prosinca 1960. godine 105. vazd. nastavni puk (klipni) - od prijašnje 2. pilotske škole i dijela 1. pilotske škole, koji je također prebačen u Zemunik, a na aerodromu Pula obnovljen je 185. vazd. nastavni puk (mlazni). SR-MJRV-RVPVO, Istorijati Komande JRV za 1960. i 1961. godinu. 
tivnih starješina, utjecale su na to da su osobna, obiteljska, statusna i materijalna pitanja postala preokupacija mnogih starješina. Iznenadna nesigurnost vojnoga poziva utjecala je na to da dio starješina pruži otpor prijevremenom umirovljenju ili da se mlađi starješine okreću tajnom izvanrednom studiranju na civilnim fakultetima (posebno u Zagrebu i Zadru) da bi na taj način stekli kvalifikacije i mogućnost da se bolje snađu izvan vojnoga sistema ako bi to bilo potrebno.

U tom se periodu negdje oko 1960. pojavljuju prve „afere” u vojnom vrhu: val smjenjivanja ratnih kadrova srpske i crnogorske nacionalnosti kao posljedica njihova većega broja, njihove neodgovarajuće školske spreme i potreba nove organizacije. $\mathrm{Na}$ to će se nadovezati val umirovljenja mlađih starješina oko 1964., vođen idejom balansiranja nacionalnoga sastava oficirskoga kadra prema nacionalnoj zastupljenosti u državi. Svi ti trendovi dovest će do postupnoga uvođenja „nacionalnoga ključa” za pojedine najviše rukovodeće dužnosti u Armiji. To je nagovijestilo da ni Armija neće biti pošteđena utjecaja iz civilnoga društva, i pored permanentnoga održavanja prividne slike potpunoga jedinstva vojnoga vrha. ${ }^{65}$

Odluke IV. („Brijunskoga”) plenuma Centralnoga komiteta Saveza komunista Jugoslavije 1. srpnja 1966. ostavile su znatne posljedice na organe sigurnosti JNA iako nisu bile toliko vidljive u svjetlu potresa koji se dogodio u Državnoj sigurnosti. Tim povodom održani su sastanci u svim organizacijama Saveza komunista Jugoslavije u JNA - u armijskim oblastima, vojnim područjima, divizijama, pukovima i drugim jedinicama. Odluke, zaključci i konkretni zadaci proistekli iz odluka IV. plenuma rukovodstvu Službe sigurnosti preneseni su na mjesečnim savjetovanjima u Upravi sigurnosti JNA 1966. godine. Rad Službe bio je tema 5. sjednice Opunomoćstva Centralnoga komiteta Saveza komunista Jugoslavije za JNA u rujnu 1966., koje je zaključilo da „Služba bezbednosti JNA nema nikakve veze sa političkim zloupotrebama u vrhovima Državne bezbednosti niti sa deformacijama zbog kojih je Državna bezbednost pokušala da se pretvori u silu iznad društva”. Na osnovi opširnoga izvještaja načelnika Uprave sigurnosti generala Ivana Miškovića „o celovitom radu Službe bezbednosti JNA", i vrhovni komandant Josip Broz Tito pozitivno je ocijenio rad Službe. Tijekom 1967., u ubrzanoj proceduri, doneseno je novo pravilo organa sigurnosti JNA. U njemu je precizirano kako se i po čijem ovlaštenju primjenjuju specijalne snage i sredstva. ${ }^{66}$

Politička afera uklanjanja iz političkoga života potpredsjednika SFRJ Aleksandra Rankovića nakon Brijunskoga plenuma 1966. snažno je utjecala na to da dio njegovih najbližih suradnika bude uklonjen s dužnosti, umirovljen i isključen iz javnosti. Tako je i državni sekretar za narodnu obranu general armije Ivan Gošnjak 1967. smijenjen s te funkcije i postavljen za člana Savjeta Federacije. On je svakako bio smijenjen zbog neangažiranja na Brijun-

65 Razvoj OS SFRJ, knj. 24: Rukovodeći kadar oružanih snaga, 80-96; BJELAJAC, Jugoslovensko iskustvo sa multietničkom armijom 1918-1991, 54-73.

66 KOVAČ, DIMITRIJEVIĆ, POPOVIĆ, Slučaj Ranković, 325-328. 
skom plenumu protiv svojega prijatelja Rankovića. Ali uočljivo je da je Služba sigurnosti procijenila da se u vrhu komentiralo da su „između njega i ostalih rukovodilaca izbila neka neslaganja u vezi koncepcije Armije i narodne odbrane, da je nastala nesloga oko zahteva o stvaranju nacionalnih armija". ${ }^{67}$ Ipak, sve do kraja 60-ih republičke vlasti nemaju nikakve konkretne nadležnosti ni organe za poslove obrane. Obrana je potpuno na saveznoj razini i u suštini potpuno u Titovim rukama.

\section{Nastavak smanjenja efektiva kroz plan „Snaga” i iznenadna „čehoslovačka kriza” 1968. godine}

Ponesen sveopćim napretkom odnosa s istočnim blokom, vojni vrh naredio je 25. prosinca 1967. da se provede daljnje smanjenje mirnodopskih efektiva JNA tijekom 1968. godine. Tako su mnoge pješadijske divizije preformirane u pukove, a njihovi pukovi u bataljone i tako naniže. Na teritoriju SR Hrvatske u 5. armijskoj oblasti (komandant general-pukovnik Đoko Jovanić) na razinu puka „spuštene” su sljedeće divizije: 6. proleterska u Karlovcu i 12. u Osijeku, odnosno samostalni pješadijski pukovi: 9. u Kninu, 13. u Gospiću i 32. u Zagrebu. Tada su rasformirani 11. proleterska brigada u Kninu i 145. pješadijski puk u Koprivnici. Preformiran je i veći broj rodovskih jedinica kopnene vojske. ${ }^{68}$

Uslijedilo je rasformiranje vojnih područja: od njih ukupno trinaest, $u$ Hrvatskoj su bila tri, a umjesto njih naređeno je formiranje pet korpusa, od kojih su se dva nalazila u Hrvatskoj (4. u Rijeci i 10. u Zagrebu). U 4. armijskoj oblasti (komandant viceadmiral Bogdan Pecotić) ukinuta su dva vojna područja (jedno u Šibeniku). Na taj način za komandu oblasti vezuju se isključivo tri vojnopomorska sektora, koji i dalje zadržavaju veći broj raznorodnih jedinica vezanih za sebe. U skladu s tim napravljene su promjene u komandama armijskih oblasti i u jedinicama veze, koje su prilagođene novoj organizaciji bez vojnih područja. ${ }^{69}$

Naredbom iz srpnja 1968. u „ratnoj” armiji formirane su grupe za razvoj teritorijalnih pješadijskih pukova. Te komande nastale su preformiranjem prijašnjih partizanskih brigada R. ${ }^{70}$ Konačno, kolovoškom naredbom formirane su komande 22 vojna okruga - kao vojno-teritorijalnih organa, od kojih je pet bilo smješteno u Hrvatskoj, i to Zagrebu, Splitu, Rijeci, Osijeku i Karlovcu. ${ }^{71}$

$67 \quad$ Isto, 388-391.

68 SR-MO-SLJR-UO, Nar. DSNO, str. pov. 602, 25. 12. 1967. Po toj naredbi garnizon Nova Gradiška (288. samostalni mješoviti protutenkovski artiljerijski divizion) ušao je u sastav 5 . armijske oblasti.

69 SR-MO-SLJR-UO, Nar. DSNO, str. pov. 28, 20. 1. 1968. Prema naredbi DSNO-a str. pov. od 5. 3. 1968. izmijenjena je organizacija artiljerijskih jedinica.

70 SR-MO-SLJR-UO, Nar. DSNO, str. pov. 345, 16. 7. 1968. Od 29 formiranih, pet pukova formiralo bi se u Hrvatskoj, i to: 508. u Splitu, 510. u Osijeku, 563. u Zadru, 547. u Slavonskoj Požegi i 588. u Kninu. Na njihovu mjestu ukinute su komande partizanskih brigada.

71 SR-MO-SLJR-UO, Nar. DSNO, str. pov. 420, 20. 8. 1968. 
Agresija snaga Varšavskoga ugovora na Čehoslovačku 20. kolovoza 1968. došla je za jugoslavenski vojno-politički vrh potpuno iznenadno. Najveći dio rukovodećega sastava nalazio se na godišnjem odmoru, a procjene Vojnoobavještajne službe nisu sugerirale nikakvu opasnost. ${ }^{72}$ Suverenitet Jugoslavije bio je pred ozbiljnim iskušenjem od „ideološke subraće” s Istoka samo dva desetljeća nakon Informbiroa. Olako prepuštanje komunističkom internacionalizmu pokazalo se kao neopravdano i opasno. Pogotovo je iznenađenje bilo veće kad se uzme u obzir intenzivna vojno-tehnološka suradnja od 1961., odnosno jugoslavensko vojno planiranje koje nije pretpostavljalo nikakvu opasnost od istočnih susjeda - članica Varšavskoga pakta. Čak naprotiv, u eventualnom sukobu računalo se na nuklearnu „podršku” koju bi taj savez pružio Jugoslaviji.

Jedinice JNA koje su gravitirale prema istočnim susjedima prevedene su u viši stupanj borbene gotovosti već idućega jutra. Naređena je, među ostalim, mobilizacija dijela jedinica 5. armije. Aktivirane su neke jedinice ešalona B i djelimice je mobiliziran rezervni sastav i vozila iz popisa radi dopune jedinica tipa A i A-1. Aktivirana je 265. oklopna brigada i raspoređena prema Mađarskoj. Dio jedinica zauzeo je položaje na važnijim točkama unutar zemlje gdje se očekivao zračni desant, na civilnim i vojnim aerodromima. ${ }^{73}$

U 5. vazduhoplovnom korpusu nakon dobivanja signala za uzbunu snage su razmještene kako slijedi: 15. divizija PVO bila je s komadom 5. puka VOJIN na Komandnome mjestu u Buševcu. Jedan bataljon toga puka razmješten je na lokacijama u unutrašnjoj Hrvatskoj i Sloveniji: Kurilovec, Sisak, Donji Miholjac, Pleso, Koprivnica, Donja Lendava, drugi bataljon bio je lociran u Ljubljani i po dijelovima na Monte Kope kod Pule, Muzilu i u Umagu. U letačkim jedinicama korpusa po jedno odjeljenje bilo je u pripravnosti br. $1 \mathrm{i}$ br. 2 , a samo je u 117. lovačkom puku ostatak držan u pripravnosti br. 3. Cerkljanska 82. aviobrigada ostala je sa 237. eskadrilom na matičnom aerodromu, a njezina 238. eskadrila prešla je na aerodrom Pleso. Zagrebački 155. raketni puk imao je sa po tri lansera na svojim vatrenim položajima gotovost za djelovanje do šest minuta. Jedinice toga puka ostale su u blizini svojih garnizona, a samo je 2. raketni divizion PVO bio isturen u noći 31. kolovoza / 1. rujna na položaj Lupoglav sjeverno od Ivanić-Grada. Jedan od najvidljivijih uspjeha u toj operaciji bio je neprekidni 48-satni rad raketno-tehničkoga diviziona 155. puka na pripremi i otpremanju raketa na položaje. Od 15. rujna primjenjivane su posebne procedure za letenje, zabranjene zone i sistem identifikacije zrakoplova. Ocijenjeno je da je u svim zadacima pokazan visok stupanj obučenosti ljudstva i idejno-politička monolitnost. Naprezanje zrakoplovnotehničke službe bilo je maksimalno jer je rad bio neprekidan. To angažiranje trajalo je od kraja 21. kolovoza do 13 sati 7. listopada 1968. i ostalo je poznato kao zadatak „Avala”. ${ }^{74}$

72 Razvoj OS SFRJ, knj. 13: Vojnoobaveštajna služba, 309-311.

73 SR-VA-JNA, zatvorena građa, svežanj 4555, 20. „Iskustva iz aktiviranja oklopnih jedinica po planu Avala."

74 SR-MJRV-RVPVO, kut. 27, „Istorija 5. VaK, 1964-1972”, 94-95. 
S druge strane bilo bi zanimljivo istražiti koliki je bio stvarni angažman snaga Varšavskoga pakta prema Jugoslaviji u tom trenutku i je li agresija realno bila planirana i izvediva. Ovako se stječe dojam da je vojno-politički vrh SFRJ reagirao impulzivno s idejom da ne dozvoli nikakvo iznenađenje, ali i da pokaže da je spreman braniti se u slučaju eventualnoga napada. To je svakako uzeto u obzir i u Varšavskom i Sjevernoatlantskom paktu. Nakon „čehoslovačke krize” gotovo odmah je nastavljena suradnja sa Sovjetskim Savezom u poslovima nabavke naoružanja, a na Zapadu se Jugoslavija otad ponovo počela držati jasno drugačijom od ostatka komunističkoga svijeta, što je omogućilo i obnavljanje vojne suradnje, prije svega u domeni nabavke naoružanja i tehnološke suradnje.

\section{Promjene nakon „čehoslovačke krize”}

S koncepcijske točke gledišta zanimljiva je činjenica da je agresija na Čehoslovačku izmijenila percepciju budućega neprijatelja koja je postojala u ratnim planovima „Drvar”, „Drvar 2” i tada aktualnom planu „Snaga”, gdje se računalo isključivo na agresiju sa Zapada. Sada je iskustvo krize nametnulo odbacivanje idejnoga koncepta plana "Snaga” i njegovu modifikaciju u plan „Snaga 2", a kasnije stvaranje novoga organizacijskog plana „Rudo”, koji je uključio i mogućnost agresije s Istoka. Prije svega mislilo se na mogućnost agresije iz pravca Mađarske i Bugarske. Analizirana je prijetnja iz zraka, najviše u vidu zračnih desanata, što je bio utjecaj upada sovjetskih zračnodesantnih jedinica u Čehoslovačku, i mogućih zračnih udara na grupirane snage oklopnih jedinica prema iskustvima s Bliskoga istoka 1967. godine. Smatramo da se utjecaj tako sagledanih prijetnji na sigurnost SFRJ umnogome odražavao na praksu organiziranja, obuke i filozofije upotrebe jedinica JNA sve do sredine 80 -ih godina.

Ta kriza utjecat će na niz promjena u sistemu obrane: pojačavanje garnizona na određenim kritičnim pravcima, daljnje forsiranje domaće vojne proizvodnje, zaustavljanje vala umirovljenja mladih starješina, poboljšanje materijalnoga i statusnoga položaja vojnih osoba, redefiniranje nove strukture ratne vojske, stvaranje armijskih komandi u sjedištima republika i prve korake u stvaranju Teritorijalne obrane kao novoga vida oružanih snaga $\mathrm{u}$ ratnoj formaciji, odnosno kao „najšireg oblika organizovanja građana za opštenarodni oružani otpor".

Prema iskustvima iz krize, već ujesen 1968. obnovljen je val reorganiziranja jedinica. I to upravo kad je završen proces prethodne reorganizacije s početka godine! U Osijeku je 12. samostalni pješadijski puk preformiran u 12. proletersku brigadu s jedinicama u Slavonskoj Požegi, Našicama i Vukovaru, a preformirani su i 9. pješadijski puk u Kninu i 13. pješadijski puk u Gospiću. Sve tri oklopne brigade u SR Hrvatskoj (2., 31. i 265.) postale su samostalne jer je rasformirana 7. oklopna divizija u Sisku. Ponovo je formirano 18 komandi partizanskih divizija, od kojih su četiri bile u Hrvatskoj: 7. (Karlovac), 33. 
(Bjelovar), 35. (Gospić) i 40. (Slavonska Požega), kao i grupe za razvoj 23 ratne brigade, od kojih pet u Hrvatskoj. ${ }^{75}$

Potom je dio jedinica premješten (dijelom i iz Slovenije), a razne su jedinice pomaknute da bi se formirao novi raspored na prostoru oko Zagreba. Od nekoliko bataljona iz ratnih garnizona reorganiziran je 32. samostalni pješadijski puk (u ratu: 32. divizija) u Sisku i Petrinji, a formiran je novi 73. pješadijski puk u Koprivnici, dijelom u Virovitici i Bjelovaru. ${ }^{76}$ Došlo je do preformiranja divizijskih artiljerijskih pukova, protuavionskih jedinica, inženjerijskih i jedinica veze i izmještanja mobilizacijskih mjesta nekih ratnih partizanskih brigada ili ratnih pukova. ${ }^{77} \mathrm{Na}$ svim civilnim aerodromima (Pleso, Čilipi, Grobničko polje, Pula, Zadar i Split) trebalo je u ratu formirati jedinice osiguranja borbene avijacije koja bi zaposjela i te aerodrome. ${ }^{78}$

Tijekom 1969. nastavljeno je vraćanje pješadijskih pukova u rang divizija, koje su neposredno prije „čehoslovačke krize” spuštene na razinu pukova: 6 . proleterska u Karlovcu, 9. u Kninu i 32. u Sisku, kao i reorganiziranje i stvaranje novih manjih rodovskih ili pomorskih jedinica. ${ }^{79}$

Jedna od najvećih promjena koja je uslijedila u tom periodu bila je odluka da se armijske oblasti ponovo preformiraju u armije. One su u nekim slučajevima bile približno jednake republičkim granicama (3. u SR Makedoniji, 7. u SR Bosni i Hercegovini i 9. u SR Sloveniji, odnosno Vojno područje Titograd u SR Crnoj Gori). Komanda 5. armijske oblasti u Zagrebu sada je postala 5. armija (komandant general-pukovnik Đoko Jovanić), a komanda 4. armijske oblasti u Splitu Vojnopomorska oblast (komandant viceadmiral Ljubo Truta) ${ }^{80}$

Kad se pogleda raspored garnizona prema toj promjeni, vidi se da je SR Hrvatska (kao i SR Srbija) bila i dalje organizacijski „pokrivena” s više armija. Tako je teritorij SR Hrvatske bio najviše obuhvaćen 5. armijom, koja je dijelom ulazila na teritorij SR Slovenije (garnizoni Ilirska Bistrica-Kozina) i SR Bosne i Hercegovine (Bihać); zatim Vojnopomorskom oblašću, koja je pokrivala cjelokupnu dalmatinsku obalu i otoke ; centralni i istočni dio Slavonije bio je u nadležnosti 7. armije s komandom u Sarajevu. Stvaranjem armija ukinuti su kratkotrajni korpusi i dio njihovih prištabnih jedinica. Takva organizacija armija funkcionirat će sve do kraja 1988. godine.

Povijest razvoja jedinica JNA u idućih dvadesetak godina na strateškoj je razini stabilna jer se komande armija ne mijenjaju, dijelom i komande aktivnih i ratnih divizija, uz tek nekoliko iznimaka. Tako je bilo i u SR Hrvatskoj. Razvoj organizacije pratimo kroz promjene na brigadno-pukovskoj razini ili (pre)formiranje jedinica koje su zahtijevali nova tehnika i naoružanje uvođeni

75 SR-MO-SLJR-UO, Nar. DSNO, str. pov. 529, 20. 9. 1968.

76 SR-MO-SLJR-UO, Nar. DSNO, str. pov. 562, 8. 10. 1968.

77 SR-MO-SLJR-UO, Nar. DSNO, str. pov. 592, 24. 10. 1968.

78 SR-MO-SLJR-UO, Nar. DSNO, str. pov. 584, 18. 10. 1968.

79 SR-MO-SLJR-UO, Nar. DSNO, str. pov. 35, 20. 1. 1969.

80 SR-MO-SLJR-UO, Nar. DSNO, str. pov. 658, 22. 11. 1968. 
u tom periodu. U javnosti, pa i političkom životu, u iduća dva desetljeća doći će i do djelomične identifikacije komandi armija kao dijela republičkih institucija, što će biti posebno karakteristično krajem 80-ih godina.

Period 60-ih godina u JNA s jedne je strane veoma intenzivan u modernizacijskom smislu, a s druge strane to je desetljeće s najviše organizacijsko-formacijskih promjena. Ukupno ih je bilo šest, ali kako su se često prelijevale jedna u drugu uslijed kašnjenja ili utjecaja novih događaja, teško je utvrditi njihove realne domete. Za taj niz promjena u JNA s često pogrešnim rješenjima u suštini nije nitko odgovarao, makar i simbolično, a organizacijske promjene donosile su velike troškove u seljenju vojnih efektiva, preseljenje aktivnoga sastava iz jednih u druge gradove, a znatan dio aktivnoga sastava koji je u tom desetljeću zbog čestih promjena gubio perspektivu u Armiji potom ju je napuštao. Na organizaciju JNA u tom razdoblju utjecala je nova doktrina općenarodnoga rata, postojali su i američki, potom i sovjetski vojni utjecaji, zatim pokušaji da se s postojećim snagama postignu očekivani dometi novih organizacija, i konačno iznenadna „čehoslovačka kriza” 1968., koja je JNA „uhvatila” u raskoraku između organizacijskoga smanjenja i političkoga povjerenja u države Varšavskoga pakta. Taj je događaj definitivno promijenio percepciju potencijalnih agresora i potom je stvorena organizacija JNA koja se uglavnom nije mijenjala idućih dvadeset godina, sve do porasta političkih tenzija u SFRJ krajem 80-ih godina.

\section{Arhivski i neobjavljeni izvori}

SR-MJRV-RVPVO: Srbija, Muzej Jugoslovenskog ratnog vazduhoplovstva, Aerodrom Beograd, fond (posleratnih) jedinica Ratnog vazduhoplovstva i protiv vazdušne odbrane.

SR-MO-SLJR-UO: Srbija, Ministarstvo odbrane, Sektor za ljudske resurse, Uprava za organizaciju, Beograd, Naredbe DSNO / III Uprave Generalštaba JNA za organizacijsko-mobilizacijske promene.

SR-VA: Srbija, Vojni arhiv, Beograd:

- JNA: fond Jugoslovenske narodne armije (otvorena i zatvorena građa).

- VBA: fond Vojnobezbednosne agencije.

\section{Interne publikacije Jugoslavenske narodne armije}

Druga eskadrila Narodnooslobodilačke vojske Jugoslavije 1944-1984. Izdala komanda VJ 5870 Cerklje, juli 1984.

Razvoj oružanih snaga SFRJ 1945-1985: knj. 3: Kopnena vojska JNA, tom I-III; knj. 5: Ratna mornarica; knj. 9: Pozadina, tom I-III; knj. 10: Vojno školstvo JNA; knj. 12: Vojna bezbednost; knj. 13: Vojnoobaveštajna služba; knj. 24: Rukovodeći kadar oružanih snaga. Beograd, 1986-1991.

Trideset godina Školskog centra PVO. Zadar: ŠC PVO, 1975. 


\section{Literatura}

BJELAJAC, Mile S. Jugoslovensko iskustvo sa multietničkom armijom 1918-1991. Beograd: UDI, 1999.

BOŠKOVIĆ, Rajica. Nebo na dlanu. Vek vazdušnog osmatranja, javljanja $i$ navođenja. Beograd: Autorsko izdanje, 2017.

Čuvari našeg neba. Beograd: Vojnoizdavački zavod, 1977.

DIMITRIJEVIĆ, Bojan. Jugoslavenska narodna armija u Hrvatskoj i Sloveniji 1945. - 1968. Zagreb: Despot Infinitus, 2017.

DIMITRIJEVIĆ, Bojan. „Organizacija Jugoslovenske narodne armije u Hrvatskoj 1945-1965. godine”. U: Dijalog povjesničara - istoričara 9. Ur. Fleck, Hans-Georg i Graovac, Igor, Zagreb: Friedrich Naumann Stiftung, 2005, 301-320.

DIMITRIJEVIĆ, Bojan. „Organizacija Jugoslovenske narodne armije u Hrvatskoj 1966-1991. godine”. U: Dijalog povjesničara - istoričara 10. Ur. Graovac, Igor, Zagreb: Friedrich Naumann Stiftung, 2008, 119-138.

JOVANOVIĆ, Aleksandar S. Poraz. Koreni poraza. Veternik: LDJI, 2001.

KOMAR, Milan, prir. Podmorničarstvo Jugoslavije. Beograd; Ljubljana; Pula: Udruženje Podmorničar Beograd; Društvo Podmorničar Ljubljana; Udruga Podmorničar Pula, 2012.

KOVAČ, Svetko; DIMITRIJEVIĆ, Bojan; POPOVIĆ, Irena. Slučaj Ranković: iz arhiva KOS-a. Zagreb: Despot Infinitus, 2016.

PRIBILOVIĆ, Kažimir. „Uz četrdesetogodišnjicu početka rada Vojnopomorskog učilišta JRM”. Mornarički glasnik (1986), br. 4: 854-862. 


\section{SUMMARY}

\section{The Yugoslav People's Army in the Socialist Republic of Croatia 1959-1969}

The article provides an overview of the organisational development of the Yugoslav People's Army (YPA) in the Socialist Republic of Croatia (SRC) during the 1960s. The organisational development of YPA units in the SRC was generally almost identical to that of YPA units in the other Yugoslav republics. The development of the Navy, however, was different. There were several organisational changes that affected the YPA units in the SRC in this period. The first of these was the plan 'Drvar' in 1959, which introduced many new organisational forms inspired by experiences from Yugoslav Partisan warfare in World War II and by war in expected nuclear conditions. Due to some radical solutions that actually burdened the functioning of the YPA, a new organisational plan, 'Drvar II', was introduced in 1964 to amend this. It was followed by further reorganisations: one in 1965, which adjusted the names and traditions of the Partisan units and existing YPA units, another in 1966-1968, entitled 'Snaga' (Power), which led to the downsizing of the YPA following the notion in the highest Yugoslav military circles that foreign aggression was only possible from the NATO side. The sudden Warsaw Pact aggression on Czechoslovakia in August 1968 brought change in the Yugoslav perception of possible aggressors, which now included the neighbouring communist countries. This led to another organisational change entitled 'Snaga II'. Looking from a distance, it seems that organisational changes in the YPA during the 1960s were endless. The article also notes the YPA turn to the Soviet Union for the purchasing of the modern military equipment, ranging from main battle tanks to supersonic fighters. It was written on the basis of the still-restricted sources of the Yugoslav General Staff that are kept in the Organisational Department of the Republic of Serbia's Ministry of Defence.

Key words: Yugoslav People’s Army; Socialist Republic of Croatia; Yugoslavia; organisation; units; ground forces; air force; navy 